Article

\title{
Candlelight for Our Country's Right Name: A Confucian Interpretation of South Korea's Candlelight Revolution
}

\section{Sungmoon Kim}

Department of Public Policy, City University of Hong Kong, 83 Tat Chee Avenue, Kowloon, Hong Kong; sungmkim@cityu.edu.hk; Tel.: +(852)-3442-8274

Received: 10 September 2018; Accepted: 26 October 2018; Published: 28 October 2018

\begin{abstract}
The candlelight protest that took place in South Korea from October 2016 to March 2017 was a landmark political event, not least because it ultimately led to the impeachment of President Park Geun-hye. Arguably, its more historically important meaning lies in the fact that it marks the first nation-wide political struggle since the June Uprising of 1987, where civil society won an unequivocal victory over a regime that was found to be corrupt, unjust, and undemocratic, making it the most orderly, civil, and peaceful political revolution in modern Korean history. Despite a plethora of literature investigating the cause of what is now called "the Candlelight Revolution" and its implications for Korean democracy, less attention has been paid to the cultural motivation and moral discourse that galvanized Korean civil society. This paper captures the Korean civil society which resulted in the Candlelight Revolution in terms of Confucian democratic civil society, distinct from both liberal pluralist civil society and Confucian meritocratic civil society, and argues that Confucian democratic civil society can provide a useful conceptual tool by which to not only philosophically construct a vision of civil society that is culturally relevant and politically practicable but also to critically evaluate the politics of civil society in the East Asian context.
\end{abstract}

Keywords: Candlelight Revolution; civil society; Confucianism; impeachment; South Korea

The candlelight protest that took place in South Korea (hereafter Korea) from October 2016 to March 2017 was a landmark political event, not least because it ultimately led to the impeachment of President Park Geun-hye, the daughter of Park Chung-hee, former military dictator and icon of Korean conservatism. Its more historically important meaning is perhaps that it marks the first nation-wide political struggle since the June Uprising of 1987, where civil society representing the national alliance of citizens won an unequivocal victory over a regime that was found to be corrupt, unjust, and undemocratic. While the 1987 June Uprising was a victory for citizens over an authoritarian regime, thereby bringing about Korea's democratization, the 2016-2017 candlelight protest signified a victory for the citizens over Korea's political past characterized by "accumulated evils" (chǒkp'ye 적 폐) that had been preventing Korea from advancing into a truly democratic and just society. For Koreans, Park's abuse of power in extorting millions of dollars from big corporations (also known as chaebol) to fund foundations created by Choi Soon-sil, her private confidante, Choi's improper and illegal meddling in governmental affairs, and Choi's daughter's shady admission into one of the most prestigious universities in Korea using the connection to the president all signaled the culmination of the accumulated evils, which ought to have been overcome in order for Korea to live up to its normative ideal or its true name as a democratic republic—hence the slogan "ige naranya 이게 나라냐? (Is this a country?)" throughout the protest.

Park was removed from office on 9 March 2017 when the Korean Constitutional Court (KCC) upheld the motion to impeach her. Since then a number of studies have been and are still being produced that aim to evaluate the social and political significance of what is now called "the Candlelight 
Revolution"1 as well as to understand the reason for its success, and they have identified several factors as being directly conducive to the victory of civil society: Remarkable order and civility shown by the protesters, the protest's festival-like outlook and operation, and the educational effect of the protest in producing bold, persistent, and yet non-violent citizen activism which built staggering pressure for the political parties to join civil society and eventually to pass the motion of impeachment in the National Assembly. ${ }^{2}$

Less attention, however, has been paid to what galvanized millions of ordinary Koreans to take to the streets in the first place, who are otherwise radically polarized politically, seriously divided by generational differences, and increasingly pluralized as Korean society becomes more liberal and multicultural. One possible explanation could be that Koreans' deep commitment to liberal constitutionalism propelled them to the streets when they found out that the president had critically violated citizens' constitutional rights to private property and more importantly to life (especially, the victims of the "Sewol incident" as will be discussed later). Indeed, this turned out to be one of the key factors that the KCC took seriously in adjudicating Park's impeachment as it saw its core task as preserving Korea's "liberal and democratic constitutional order." But it is difficult to believe that violation of liberal-constitutional rights as such was the major driving force of the nation-wide mass protest, encompassing citizens of all generations, given that similar, even more serious, violations had been committed on several occasions by Park's administration.

If protection of liberal rights was not the most salient motivation of the 2016-2017 Candlelight Revolution, perhaps the protection of democracy? In fact, many scholars agree that the Candlelight Revolution can be better understood as a revolution for democracy, that is, as the citizens' protest against the president's forfeiture of democratic legitimacy upon her violations of the law, including the illegal entrustment of important governmental decisions to her personal friend, who had no experience in public affairs, let alone the democratic mandate to act on behalf of the president. But if it is not (necessarily) liberal rights per se that constitute the essence of Korean democracy, what was at stake in the winter of 2016-2017? What kind of democracy did Korean citizens have in mind when their rancorous voices uniformly chanted "ige naranya"? In order to understand the nature of the public frustration that developed into a civil uproar as well as the collective motivation that animated long-sustained civic activism ultimately resulting in the impeachment of the president, therefore, it is imperative to investigate how democratic legitimacy is understood by Koreans, what counts as its critical violations, and how rectification of such violations have been pursued in both traditional and contemporary Korea. Though there may be multiple discourses available to this effect, this paper pays attention to the Confucian moral discourse, which explains the viability of Korean civil society and democratic politics more generally from the perspective of Confucian ethics and values.

There are two reasons for my attention to Confucianism regarding this event. First, despite the conventional view of Confucianism as the single greatest obstacle to Korea's evolution into a modern state and society, many observers have repeatedly pointed out that Koreans are still deeply saturated with Confucian values and moral sentiments, creating an interesting tension between liberal democratic institutions, rights, and values, on the one hand, to which the Korean polity is formally and directly committed, and Confucian societal culture on the other, which continues to inform, often unwittingly, Koreans' habits of the heart, their increasing diversity notwithstanding. From this viewpoint, what appears to be culturally blind or neutral moral arguments that aim to constrain the political leaders

1 Most notably, see Son (2017). Ongoing controversy notwithstanding, I call the candlelight movement that took place in 2016-2017 the Candlelight Revolution not least because it was the only politically successful candlelight movement, but more importantly, this success was achieved within the constitutional structure, bringing the social and political aspirations expressed in the previous mass candlelight movements to their institutional culmination. In this regard, I agree with Nan Kim, when she says, "the Candlelight protesters achieved something far more durable and politically stabilizing by bringing public pressure to bear upon the working of democratic institutions to ensure that the checks instituted by their Constitution would successfully guard against a tyrannical president and one otherwise unfit for office" (Kim 2017, p. 15).

2 See generally Kim and Lee (2017) and Kim (2018). 
and hold them accountable to the public can turn out to be meaningfully Confucian, representing Koreans' shared normative ideals rooted in their traditional conception of the good government. The second reason is more straightforward, that scholars in Korea and beyond are increasingly persuaded of the important role played by Confucianism during Korea's democratization and in the development of Korean civil society. Rather than dismissing this emerging literature as simply idiosyncratic or misinformed, which has largely been the case in Korean social sciences and Korean studies, this paper extends its core findings and arguments to a new interpretation of the Candlelight Revolution and illuminates the underappreciated connection between traditional Confucian moral discourse and contemporary Korean politics.

In investigating public motivation behind the Candlelight Revolution from a Confucian perspective, this paper has an additional aim in relation to theory-building. By understanding the Candlelight Revolution as a political and constitutional achievement of Korean civil society, it also aims to examine its nature in reference to Confucian moral discourse and present a normative model of Korean civil society that is democratic, progressive, and deeply ethical in terms of Confucian democratic civil society, distinct from both Confucian meritocratic civil society, marked by moral elitism and epistemic optimism, and liberal pluralist civil society, centered on protection and expression of interests and/or values.

\section{Culture and "Confucianism": A Methodological Note}

Before embarking upon the Confucian interpretation of the Candlelight Revolution, an explanation seems to be necessary for how I intend to achieve this paper's dual goals-to understand the Candlelight Revolution from a cultural standpoint, on the one hand, and build a normative theory of Confucian civil society by which to justify and evaluate a non-liberal feature of Korean democratic civil society, on the other.

The first question that I would like to address has to do with the term "Confucianism". In normative Confucian political theory Confucianism is commonly understood as a philosophical system (more or less) clearly distinct from other "comprehensive doctrines" such as liberalism. In critical cultural studies, however, culture is viewed not so much as a static and reified system of values that constitute the essence of the national character or determine the cognitive, conative, and attitudinal dimensions of individual agency, but rather as semiotic practice (Swidler 2000) or relational effects, or what Lisa Wedeen (2002) calls "intelligibility". ${ }^{3}$ According to critical studies scholars, it is a grave mistake to capture Confucianism (or any traditional religious or ethical tradition for that matter) in terms of comprehensive doctrine because no culture can be "comprehensive" in its make-up and empirical manifestation.

It is beyond the scope of this paper to discuss how these two markedly different approaches to Confucianism might be reconciled in a philosophically robust fashion. Committed to both empirical evaluation and normative theorization, all that this paper proposes is to understand Confucianism as a partial comprehensive doctrine that is porous to and actively interacts with other cultures, religions, and moral and philosophical doctrines. ${ }^{4}$ What renders partial Confucianism thus understood as still meaningfully (but not fully comprehensively) "Confucian" is its intelligibility as a loose constellation of moral discourse, social practice, and ethical aspiration that situates East Asians (Koreans in particular) in their "societal culture", a culture which "provides its members with meaningful ways of life across the full range of human activities, including social, educational, religious, recreational, and economic life, encompassing both public and private spheres," as Will Kymlicka (1995, p. 76) puts it. ${ }^{5}$ In this way, we have a less essentialist but more malleable concept of Confucianism that can be attributed to

3 Wedeen approaches culture as a complex set of practices of "meaning-making" through which social actors attempt to make their worlds coherent. She calls such thin coherence "intelligibility".

4 On the distinction between partial and full comprehensive doctrines, see Rawls (1993, p. 13).

5 For a more detail discussion of the so-called "intelligibility condition" of Confucian political theory, see Kim (2016, pp. 15-16). 
the societal culture of modern Koreans who are increasingly pluralist and multicultural, a concept that I hope critical studies scholars can embrace for methodological purposes, unless they completely deny the place of Confucianism in contemporary Korea. ${ }^{6}$

The second question that I want to clarify from the beginning is that it is far from my intention to fit the Candlelight Revolution into a Confucian framework. ${ }^{7}$ The danger of doing so is obvious. As many scholars observe, the Candlelight Revolution can hardly signify one single event following one simple line of social contention, such as between Park and its opponents. Its historical meaning may never be fully clear to us given our lack of God's eye, but certainly, its complex nature as a historic event can be disclosed if various contingent social relations, narratives, and contentions that coalesced into what we now call the Candlelight Revolution are taken seriously and given their due place in our account. ${ }^{8}$ The moderate aim of this paper, insomuch as it is considered a cultural study, is to bring to our attention one such narrative by casting a light on the dimension of the Candlelight Revolution that has been near-completely ignored in the existing literature, namely the connection between Confucian moral discourse and Korean democratic civil society. Yet, this aim should be evaluated against the backdrop of this paper's bigger aim of constructing a normative model of Confucian democratic civil society.

\section{Confucianism and Korean Civil Society}

In its narrowest and formal-institutional sense, "civil society" is defined as "the realm of organizations, groups, and associations that are formally established, legally protected, autonomously run, and voluntarily joined by ordinary citizens" (Howard 2003, pp. 34-35). By contrasting civil society to the primordial collectivity called Gemeinschaft by Tőnnies, however, Edward Shils pays more attention to its fundamentally ethical nature. He understands civil society in terms of "a collective self-consciousness in which the important referent is the civil quality of its participants, i.e., their being members of a society under a common authority, common laws and living in a common, more or less bounded territory" (Shils 1997, p. 71). Combining the former's formal-institutional and the latter's ethical dimensions of civil society, and with special attention to the revolutionary and emancipatory social movements that were critically instrumental to the democratization of Eastern Europe during the late 1980s, Cohen and Arato provide a more comprehensive definition of civil society that I believe is most relevant to our Korean case, when they reconceive its classical Hegelian notion mainly around "a notion of self-limiting democratizing movements seeking to expand and protect spaces for both negative liberty and positive freedom and to recreate egalitarian forms of solidarity without impairing economic self-regulation" (Cohen and Arato 1994, pp. 17-18). Rather than viewing social movements "as antithetical to either the democratic political system or to a properly organized social sphere," Cohen and Arato consider them to be "a key feature of vital, modern, civil society and an important form of citizen participation in public life" (Cohen and Arato 1994, p. 19). As such, this third conception of civil society best captures civil society's essentially dynamic, strongly participatory, deeply pluralistic, and fundamentally egalitarian characteristics that combine to work toward the protection of public space and public freedom uncoerced by both the state and the market. What undergirds civil society of this understanding is neither economic interest ${ }^{9}$ nor liberal pluralism, concentrated on negative liberty and the right to freedom of association (Galston 2002; Rosenblum 1998), but passion for democratic self-government.

6 Notice that even those who are critical of Confucianism acknowledge the substantive influence of Confucianism in shaping Korean liberalism. See Lee (2015).

7 I am grateful to an anonymous reviewer for drawing my attention to this danger.

8 For attempts to understand the political meaning of the Candlelight Revolution by placing it in its multifaceted historical context, see Kim (2017) and Doucette (2017).

9 For the notion of civil society focused on economic interest, see Diamond (1999). 
Scholars disagree as to the origin of Korean civil society ${ }^{10}$ but it is commonly agreed that the April Revolution of 1960 marks the first nation-wide and student-led democratic movement after the creation of the Republic of Korea, bringing down Syngman Rhee's authoritarian regime. The event also provided a prototype of Korean civil society for the political activists of the 1970s and 1980s when confrontational and militaristic democratic movements against the repressive state would become an integral part of Korea's everyday politics. During this democratizing period, it is frequently heard, Korean civil society grew discontent with authoritarian rule and created a counterpublic space, autonomous from the all-penetrating authoritarian state, in which left-minded intellectuals and university students (called "undongkwŏn"), otherwise weak and ephemeral as private individuals, could develop themselves into an organized political force confronting and ultimately dismantling the ruling regime. ${ }^{11}$ Sunhyuk Kim's following statement presents the nature of Korean civil society during the democratizing period in quite an illuminating way from a comparative perspective.

South Korea's democratic transition differed from certain cases in southern Europe and Latin America because conflicts, negotiations, and pacts among political elites were not the primary determinants of democratization. Rather ... it was civil society groups that initiated and directed the process of democratization by forming a prodemocracy alliance within civil society, creating a grand coalition with the opposition political party, and eventually pressuring the authoritarian regime to yield to the "popular upsurge" from below. An oppositional, resistant, and rebellious civil society was one of the most significant reasons behind the most prominent political change in South Korea's postwar history, namely, democratization (Kim 2004, p. 139, emphasis added; also see Choi 2009, pp. 77-78).

The question is, what was the ideational engine of the "oppositional, resistant, and rebellious civil society" in Korea? As noted, there is no denying that the intellectuals and university students who were the main agents of Korea's democratizing civil society were propelled by various sorts of left political ideology and political theory, including minjung sasang or minjung ideology where minjung, literally "common people" as opposed to (educated, cultural, or political) elites and leaders, signifies "those who are oppressed in the sociopolitical system but who are capable of rising up against it" (Lee 2007, p. 5). ${ }^{12}$ But the fact that the main agents of Korean civil society were mainly driven by minjung ideology does not imply that the common people themselves played the most significant role in "resurrecting, reactivating, and re-mobilizing" Korean civil society, ${ }^{13}$ even though it is true that their broad participation in the June Uprising was critically instrumental in pressuring the ruling regime to initiate democratic reform. What is more important in the present context is what kind of moral discourse was present, motivating the main protagonists of Korean civil society to organize their political confrontations with the state with a view to the interests of the common people, rather than their own.

In this regard, Namhee Lee's attention to "a discourse of moral privilege" provides an important clue, which she understands as "a practice that was embedded in the traditional role of intellectuals, a long tradition of providing social criticism" (Lee 2007, pp. 152-3). ${ }^{14}$ At the heart of Lee's observation is that the Korean tradition of social criticism is historically rooted in the Confucian legacy of

10 For a helpful survey of this debate, see Shin (2000).

11 For the characterization of Korean civil society in the 1970s and 1980s in terms of counterpublic space, see Lee (2007). Though not using this specific concept, the following studies subscribe to a similar observation: (Koo 1993a; Park 2005; Lee 1993).

12 Alternatively but similarly, Koo (1993b, p. 131) understands minjung in terms of "a broad alliance of 'alienated classes', people alienated from power and from the distribution of the fruits of economic growth."

13 For a description of Korea's democratizing civil society as "resurrected, reactivated, and re-mobilized", see Kim (2000, p. 174).

14 It is worth noting that several scholars interested in modernizing Confucianism draw attention to the Confucian tradition of social criticism as one of the vital resources upon which to build a Confucian democracy. (See Ackerly 2005; Angle 2012; Kim 2014). 
remonstrance to the ruler, expected of "students at the National Academy and the public schools, soon to be future officials." As Lee puts it, the key to social criticism was "the Confucian concept of knowledge, which was instrumental for political power and prestige and which dictated that knowledge should be employed not only to enhance one's own status and position in society but also to maintain the proper and stable order of society, 'rectifying it if gone astray and restoring it if in disarray'" (Lee 2007, p. 153). Lee's central claim is that like their Confucian predecessors the Korean minjung activists possessed "a sense of [moral] entitlement and aspiration for political power as the elites of the society" and this cultural-moral elitism enabled them to fight for the right way (dao 道)—for them democracy—often at the expense of their private interest (also see Tu 2006, pp. 220-2).

Like most social scientists, however, Namhee Lee, notwithstanding her acknowledgment of a notable connection between Confucian moral discourse and Korean civil society, does not actively explore a Confucian dimension of Korean (democratic) politics, as though traditional culture is marginal to politics, civic activism in particular, or Confucianism is no longer relevant in post-democratic Korean politics. Not surprisingly, Korean social scientists are reluctant to characterize Korean civil society during the transitional and consolidating periods as a Confucian civil society, a civil society whose ideal of civility and its mode of political engagement is deeply (but not exclusively) saturated with Confucian values, ideals, norms, and ethics. But if a moral discourse that presents intellectuals and students as representing "the conscience of the whole society" is an integral element of Confucianism and this self-imposed moral privilege gives rise to a distinctively confrontational mode of civil politics, it is difficult to understand why we cannot call this sort of civil society a Confucian civil society, distinguishing it from a Western-style civil society, in which individual rights, value pluralism, social diversity, and economic interests are central.

In conceptualizing a distinctively Chinese form of civil society, therefore, Thomas Metzger pays close attention to "the moral awareness of the scholarly elite, who defined themselves as super-citizens [struggling with the] disjunction between the completely practicable ideal order and the actual bad condition of society in the present." Central to this conception of civil society is "the utopian, top-down view of progress as based on the moral dynamism of super-citizens able to influence a corrigible state [which has] never [been] replaced by an un-utopian, bottom-up view of progress as based on the efforts of ordinary free citizens fallibly pursuing their economic interests and organized in a practical way to monitor an incorrigible state" (Metzger 2001, p. 224). As is apparent, there is an undeniably strong resonance between Lee's description of Korean civil society during the democratizing period and the Chinese-Confucian ideal of civil society advanced by Metzger.

This observation finally leads us to revisit one of the most controversial arguments on the origin of Korean civil society. In his study on the indigenous development of Korean civil society, Hein Cho traces its historical origin back to the moral and spiritual authority, distinct from political authority, of the Confucian scholar-officials who were equipped with the ritually sanctioned right to remonstrate with the king. Cho pays special attention to the equivalent right exercised by the "backwoods literati (k. sarim 士林)" who, withdrawn from the political center, immersed themselves in Confucian studies and moral self-cultivation ${ }^{15}$ but wielded tremendous moral authority over local communities in which they resided. Echoing Lee's notion of the scholarly privilege of offering social criticism, Cho claims that "critical communication, the main medium used by officials to assert the autonomy of their bureaucracy relative to the kingship, was also used by backwoods literati to assert the autonomy of their civil society relative to the bureaucracy" (Cho 1997, p. 32).

It is far from my intention to resolve the controversy on the historical origin of Korean civil society generated by Cho's provocative argument. In the present context, it is unimportant whether or not the moral privilege enjoyed by local Confucian scholars can be reasonably identified as "civil society",

15 The appearance of the backwoods literati was one of the distinctive social phenomena during the late Chosŏn Korea since the eighteenth-century. On the backwoods literati and their emergence as a political force, see Wu (1999). 
as it is understood in the Western liberal context. What is important here is the fact that there was a much stronger tradition of social criticism in premodern Korea than in China where the backwoods literati did not emerge as a key political force checking or competing with the government at the center, and this tradition of moral and political criticism from society enabled the Confucian scholars to enjoy not only moral but also (relative) political autonomy in relation to the state. This gives a new element to the idea of Confucian civil society whose concept is currently under construction. While our earlier notion of Confucian civil society, informed largely by the Chinese experience, emphasizes the Confucian intellectuals' epistemic optimism and their moral authority of providing social criticism as super-citizens, the Korean experience adds here an important liberal element by highlighting moral and political autonomy held by the Confucian intellectuals within society, practically distinguished from formal state institutions. ${ }^{16}$

When an important dimension of Korean civil society is captured from the conceptual framework of Confucian civil society marked by moral elitism (or super-citizenship), epistemic optimism, moral and political autonomy, social criticism, and confrontational engagement with the state, ${ }^{17}$ then a more persuasive explanation for the cultural character of the state-society relation during the democratizing and consolidating periods can be available. This neither implies the Confucian origin of Korean civil society nor denies the influence of other philosophical traditions on its formation and operation. When we say that Korean civil society is a kind of Confucian civil society, it points to the observation that the distinctive cultural aspect of Korean civil society can be best captured with reference to the idea of Confucian civil society as constructed here. As such, in this paper Confucian civil society refers not so much to a historical reality but to a conceptual framework that can shed new light on the cultural and deeply ethical nature of Korean civil society that has been socially active in contemporary Korea. Is this framework still relevant in post-democratic Korea, especially in illuminating the driving force of the Candlelight Revolution? I now turn to this question.

\section{Candlelight Revolution: Dis/Continuity with Old Democratization Movement}

Even if it is agreed that the ethical dimension of Korean civil society during the democratizing and consolidating periods can be captured in terms of a Confucian civil society as defined above, it may nevertheless be forcefully opposed that it is far-fetched to suppose any meaningful connection between the candlelight protest and Confucianism. One may even claim that in post-democratic Korea the nature of civil society has undergone a dramatic change. In the course of democratic consolidation in the 1990s, the argument goes, Korean civil society, whose main locomotive thus far had been the minjung movement, was transformed into what Korean social scientists call the "citizens' movement" (simin undong), a new and more everyday form of social movement initiated by citizens themselves who, being internally diverse in their beliefs, values, economic interests, and political orientations, are organized into numerous voluntary groups, organizations, and associations, pursuing not so much revolutionary political goals with radical political means but pragmatic social goals in the service of their sectional or pluralist interests using moderate means. For many Korean social scientists, the

16 On this broad conception of "liberal" with reference to the Confucian tradition, see De Bary (1983).

17 Several scholars have explored the Confucian concept of civil society but their focus has generally been on the unique mode of civility through which individuals in society are related to one another, thereby forming a fiduciary society, a society that valorizes trust and harmony over conflict and litigation. See for instance Madsen (2002) and Tan (2003). Though I believe that this is a useful way to reconstruct Confucian civil society, I cannot help feeling that it tends to downplay the creative political tension between Confucian civil society and the state in which the former can boldly confront the latter in the name of the Way in the context of pre-democratic or democratizing East Asia. Of course, this does not mean that the fundamentally antagonistic state and society relation, which is at the heart of the classical liberal notion of civil society, should be an essential component of Confucian civil society. As Tan (2003, p. 206) rightly notes, Confucian civil society's critical, even confrontational, engagement with the state denotes civil society's independence, not its stark opposition to the state. After all, Confucian civil society is not constructed by a social contract among rights-bearing individuals in the state of nature. Nonetheless, I believe that a constructive tension between the state and civil society is the defining characteristic of Korean Confucian civil society. 
citizens' movement signifies the true advent of "civil society" in its authentic liberal-pluralist sense (Cho and Kim 2007; Shin 2006).

It is understandable why Korean scholars are fascinated by and eagerly welcome the emergence of the citizens' movement. First, it offers a powerful explanation for the successful consolidation of a new democratic system in Korea, which is sharply contrasted with the greater struggles endured by its Eastern and Central European counterparts that experienced regime transitions roughly around the same time. Many political scientists agree that democratic consolidation was critically hindered in some of the key Eastern and Central European countries because, among other things, they failed to transform their grandiose, nation-wide ethical civil society into a liberal pluralist civil society, composed of citizens freely organizing themselves into various interest groups or associations. ${ }^{18}$ In marked contrast, the emergence of the citizens' movement in post-democratic Korea signifies the successful transformation of ethical civil society into a pluralist civil society and the reconstruction of the counterpublic space into an indefinite number of citizen organizations mediating between individuals and the state.

Second and relatedly, the citizens' movement signals a radical disjuncture with the previous democratic movement that I have associated with Confucian civil society with regard to the key agents: While the minjung movement was led by super-citizens who acted on behalf of ordinary citizens often at the sacrifice of their own well-being, ${ }^{19}$ the citizens' movement is organized through mutual consent among citizens who shared common interests, concerns, and goals. Driven by a monolithic ethical, political, and national cause, the minjung movement rarely allowed internal diversity, often identifying it as a dangerous sign of dissonance and fissure within the pro-democracy camp, and relied heavily on few intellectual elites comprehensively dedicated to the common good. The citizens' movement radically differs from the minjung movement in that it is an expression of social pluralism and allows, in principle, no internal hierarchy among citizens-hence no valorization of super-citizens. In theory, it is motivated by the citizens' own everyday interests arising from their ordinary life and is constitutionally protected as based on the right to freedom of association and assembly. Therefore, unlike the minjung movement that aims to create an alternative public sphere parallel to and countervailing the state with a superior moral authority, the citizens' movement operates within the given constitutional structure, thus without generating a counterpublic. ${ }^{20}$ As many Korean social scientists believe, the citizens' movement is an indispensable incubator of participatory and/or deliberative politics, commonly regarded as the backbone of democracy.

When the citizen's movement is radically differentiated from the previous minjung movement and it is viewed as constituting a more authentic form of civil society, a trouble arises when assessing the Candlelight Revolution as a civil society movement. As widely observed, the candlelight protest initially demanding Park's voluntary resignation and later her formal impeachment was initiated by a number of unorganized ordinary citizens gathering at central Seoul in order to express their deep frustration with the president's alleged crimes and utter incompetence in governance as evidenced by Choi's illegal intervention in key public affairs. In a series of public protests which, as it turned out, took place for twenty consecutive Saturdays across the whole county, citizens came from different social, political, and religious backgrounds and formed under no conspicuous organizational leadership a

18 As some leading political scientists put it, "[e]thical civil society represents 'truth', but political society [read: civil society] in a consolidated democracy normally represents 'interest'. In political society the actor is only seldom the 'nation', but more routinely 'group'. 'Internal differences' and 'conflict' are no longer to be collectively suppressed, but organizationally represented in political society" (Linz and Stepan 1996, p. 272).

19 This is not to say that there were no other participants than the educated elites involved in the minjung movement. My point is that the main engine for social reform that the minjung movement aspired to achieve came largely from social elites equipped with a self-imposed mission for political transformation. It is an interesting question, though, whether this moral elitism sat comfortably with the minjung activists' avowed vision for social egalitarianism.

20 In Jang-Jip Choi's language, in order for the citizens' movement to truly contribute to democratic consolidation, it should be a form of civil society movement freed from the zeal for mass mobilization and institutionalized into stable party politics (Choi 2009, p. 83). 
broad and bottom-up coalition of civic activism that transcended narrow sectarian interests, while fully concentrated on Park's misconduct and the "accumulated evils" that in their view had long bedeviled Korean society, of which the Choi Soon-sil scandal was the most revealing symptom. Was the candlelight protest a typical form of the citizens' movement that emerged during the consolidating stage?

There are two main reasons to believe that the Candlelight Revolution was the culmination of the citizens' movement. First, it was not guided by a radical political agenda, aimed at total social change or emancipation. Rather, it was motivated to achieve a specific political goal, that is, removal of the president from office, and a variety of nonviolent and civil forms of protest were exercised, such as visual arts, pop and traditional music, poetry and other literary writings, and, of course, public speeches and collective singing, making the public protest a semblance of a "civic festival" of the kind Jean-Jacques Rousseau valorized as an epitome of participatory democracy. Second, though initially prompted by civic rage, citizens did not express their anger violently or rise up against the president simply for the sake of bringing her down. What was remarkable about the candlelight protest was that citizens were able to sublimate their collective rage by means of democratic constitutional procedures by pressuring the political society to formally make an impeachment prosecution and the constitutional court to uphold the motion presented by the political society. In short, the candlelight protest was conducted strictly in accordance with democratic civility and the principle of constitutionalism.

That being said, however, there are equally good reasons to reject affiliating the Candlelight Revolution with a conventional form of a pluralist civil society whose institutionalization social scientists argue is essential for democratic consolidation. First of all, the citizen activism that evolved into the Candlelight Revolution does not seem to conform to the general feature of the citizens' movement that is in principle to be motivated by sectional interests. According to Jang-Jip Choi, the success of Korea's democratic consolidation critically hinges on the prospect that the so-called "politics of square", at the core of which lie mass mobilization and emotional outburst, can be successfully transformed into stable party politics undergirded by a pluralist civil society of calm reason and civility (Choi 2009, pp. 83-92). From the perspective of mainstream political science, therefore, the Candlelight Revolution is an anomaly rather than the norm in the course of liberal democratic consolidation. It is strongly reminiscent of "the politics of square" that propelled Korean civil society in the past, except that it was citizens themselves, not super-citizens, who played a central role. After all, the political society initially showed reluctance to join civil society, not to mention to impeach the president, when the Choi scandal was first brought to public attention and citizens began to protest in the streets. It was only after the bottom-up pressure from civil society that the political society joined the candlelight protest.

Second, Korean civil society during the candlelight protest remained consistently "ethical". As we have noted earlier, ethical civil society is qualitatively different from a liberal pluralist civil society as commonly understood in social sciences in that it is organized not so much around (sectional) interest but around shared norms and values that underpin collective self-consciousness which in turn includes and promotes "an attitude of self-reflexivity". ${ }^{21}$ As historically demonstrated by Poland's Solidarity Movement and Czechoslovakia's Velvet Revolution, ethical civil society, nationally mobilized in its typical form, thus representing itself as politics of square, tends to transcend internal disagreement and difference without dismissing the pivotal importance of the plurality of values, ideas, opinions, and interests in a civil life, in search of a common higher moral goal, be it communal solidarity or a life of truth against the petrified (communist) bureaucratic regime. Though the proximate cause of the revitalization of the politics of square during the candlelight protest was certainly the desire to

21 According to Keane (1998, p. 51), “Civil societies promote an attitude of self-reflexivity, by which I mean the shared understanding among socially interacting and socially interconnected subjects that their world never stands still, that it is a puzzling product of their own making, and that as subjects of inquiry into the meaning of life they are an intrinsic part of the object of their enquiries." 
remove the incumbent president, what galvanized Korean civil society throughout the whole process was citizens' collective search for an authentic democracy, a democracy that is fair and just and one that truly represents equal citizens' collective self-determination, as was implicit in their slogan "Is this a country"?

If the Korean civil society of candlelight protest is similar to an old form of Korean civil society both in its modality and in ethical nature, and yet simultaneously distanced from it in terms of the key agents and its institutional position within the entire constitutional system, how should we make sense of it? However we answer this question, it does seem inaccurate to understand the citizens' movement as having nothing to do with the previous democratization movement. In this regard, Dong-Choon Kim's following statement is worth special attention.

[W] hile distancing itself from previous movements in terms of objective and approach, the citizens' movement is closely connected to the political opposition that existed during the military dictatorship. The start of the Korean citizens' movement can be traced back to the democratization movement that strived to reform Seoul-based national politics.... These 'comprehensive' citizens' movement organizations [that were established in the 1990s such as Citizens' Coalition for Economic Justice and People's Solidarity for Participatory Democracy] implicitly set as their goal macro-structural changes in Korean society, believing that their mission was the monitor of Seoul-based national politics (Kim 2006, pp. 103-4) 22 .

Kim's statement leads us to a more puzzling question: If there is a meaningful continuity between the citizens' movement and the old democratic movement and, by extension, between the candlelight protest and the ethical civil society of the past, what does this mean for Confucianism in today's Korean politics? Does Confucianism still culturally underscore Korean civil society? Or, more moderately, does the idea of Confucian civil society still remain a useful concept in capturing a significant cultural dimension of Korean civil society?

\section{Two Kinds of Confucian Civil Society}

At first glance, the civil society of the candlelight protest appears to have nothing to do with Confucianism. It was not led by super-citizens armed with superior moral knowledge and moral authority over both the state and the common people, and furthermore, none of its participants reportedly drew on Confucianism as the source of their political activism. If the gist of Confucian civil society lies in the moral hierarchy between super-citizens as active political agents and ordinary citizens, the beneficiaries of the former's selfless devotion to the common good, thus reproducing a modern version of rule for the people, it indeed seems difficult to associate Confucianism with the candlelight protest that was fundamentally egalitarian and inclusive.

Indeed, the inegalitarian nature of Confucianism poses a serious challenge to any endeavor to make it relevant to today's democratic Korea. Despite its long history and intra-traditional diversity, Confucianism never developed from within the idea of political equality and remained un-democratic until some modern reformers began to explore its democratic transformations. Traditionally, its political ideal was a rule for the people in which the ruler assisted by Confucian scholar-bureaucrats devotes himself to the well-being of the people who have no institutional access to political participation, and as long as the ruler fulfills this "service" well, which was believed to have been mandated by Heaven, the highest moral authority in the cosmos, he enjoys full political legitimacy without being held accountable by the people. ${ }^{23}$

However, it is presumptuous to conclude that the inegalitarian nature of Confucianism makes it categorically impossible to be create a civil society consistent with the Confucian tradition. As it is

22 Elsewhere I discuss how organizations such CCEJ and PSPD (the latter in particular) have been continuing to keep the nature of Korean civil society ethical. See Kim (2008).

23 Therefore, Chan (2014) captures the Confucian conception of political authority in terms of the service conception. 
now clear, for Confucian scholar-bureaucrats, "assisting" (xiang 相) the ruler did not mean absolute obedience. For them, the fact that the ruler had the Heaven-given mandate to serve the well-being of the people implied that he was under a significant normative constraint, though without being legally checked, and, as versed in Confucian classics and immersed in a life-long process of moral self-cultivation themselves, the scholar-bureaucrats considered it their self-imposed (or Heaven-given) responsibility to keep the ruler on the right track (dao) of governance. This seminal idea of "Confucian constitutionalism" (Kim 2011) was further developed and refined during the Neo-Confucian stage when Confucian political theory was given a complex metaphysical foundation. Now, the universe was seen to be penetrated by universal moral principles ( $l i$ 理) that interconnect the natural world with the normative world and politics with ethics, integrating "all under Heaven" into a seamless whole that is internally coherent and harmonious. ${ }^{24}$

In Neo-Confucianism, by which the founding of the Chosŏn dynasty (1392-1910) in Korea was profoundly influenced (Deuchler 1992) and which still, though partially, influences the Korean conception of the good life (personal, familial, and political) (Park and Shin 2006; Bae and Park 2013), the Confucian scholar-bureaucrats acquired a special access to Heaven (or Heavenly Principle) via their virtue and scholarship and enjoyed the exalted moral authority as the successors of the lineage of the Way (dao tung 道統), which gave them moral power by which to counterbalance the ruler's political power predicated on his hereditary right. As Wood $(1995$, p. 16) puts it, their "fundamental concern was to form a view of authority that would constitute a basis for civil order and national unity but would also contain within it an acknowledgment of the moral purpose of human social life, serving indirectly to restrain the arbitrary exercise of imperial power and prevent government from degenerating into tyranny." More importantly, as Neo-Confucianism understands what is "public" (gong 公) fundamentally in ethical terms, associating it with whatever represents Heavenly Principle or the Way, scholars in society, who were not formally involved in the government, could claim with equal force their public status as the successors of the lineage of the Way and present themselves as the unflinching moral and political critics of the ruler. ${ }^{25}$

The account of Confucian civil society inspired by this Neo-Confucian political ethos has several underlying assumptions: (1) the purpose of the state is to serve the well-being of the people; (2) when the state fails to protect or actively encroaches upon people's well-being (both economic and moral), thereby departing radically from the Way, those who are committed to the Way ought to strive to rectify the state; (3) civil society refers to the public sphere created by Confucian intellectuals who are committed to the Way and it exists in parallel with the state with an aim to put it back on the right track of what traditional Confucians call "the benevolent government" (renzheng 仁政); and finally (4) the key agents of Confucian civil society are those who are dedicated to the public good, even at the sacrifice of their private interest, hence morally superior to the laypeople preoccupied with their own well-being, and they carry on the public role played by their Neo-Confucian predecessors outside the formal governmental structure. We can call this version of Confucian civil society that is directly predicated on the core premises of Neo-Confucianism Confucian meritocratic civil society. Metzger's idea of Chinese civil society fits this model perfectly.

Korea's democratizing civil society propelled by the minjung ideology also fits well the model of Confucian meritocratic civil society. One irony with the minjung ideology is that while presenting the common people (min or minjung) as its central concern and aiming to elevate them as a political force with its own distinct voice, in reality it relies heavily on a small number of dedicated political activists who act and speak on behalf of the uneducated mass who made up the majority of the Korean people in the 1970s and 1980s, when only a select few were privileged enough to receive higher education. Like Neo-Confucian scholars and scholar-bureaucrats, especially those who were most conscious of

24 For a helpful discussion on Neo-Confucian metaphysics, see Angle and Tiwald (2017, pp. 29-36).

25 For the complex meaning of gong in Neo-Confucian Korea during the Chosŏn dynasty, see Lee (2003). 
their public role as the guardians of the Public Way (gong dao 公道), but without drawing explicitly from the Confucian political discourse, the political activists of democratizing Korean civil society regarded themselves as the champions of right principles, which they associated with democracy, and fought against what they deemed to be an autocracy or (p'okchong 폭정), a government that is diametrically opposed to the ideal of a benevolent government.

It is important to note that there is always a certain moral distance presupposed between political activists and ordinary citizens in a Confucian meritocratic civil society, and this makes it difficult to present the civil society in question as an egalitarian public space of the citizens themselves. As Namhee Lee shows, when Korean civil society was most militant during the heydays of Korean democratization, it was always the civil society of select intellectuals and student activists called undongkwŏn, though it was certainly for the common people. The rare occasions in which the undongkwŏn was joined by the common people in the streets were when some members of the undongkwŏn, most commonly university students, were brutally treated or killed by the repressive state. To many ordinary Koreans, the suffering or death of young students fighting against a despotic government were reminiscent of the "Confucian martyrs" during the Chosŏn dynasty, typically often young and upright Confucian scholar-bureaucrats who were executed by the autocrat for their open and bold political criticism. For example, though the origins of the June Uprising of 1987 are complicated, its most proximate cause was undoubtedly the deaths of two university students, Park Chong-ch'ŏl, a Seoul National University student who was tortured to death by the police, and Lee Han-yŏl, a student at Yonsei University who was killed by the riot police during an anti-government protest. Their innocent deaths were portrayed in the progressive news media as well as in the public discourse as "democratic martyrs", encouraging tens and thousands of ordinary Koreans to take to the streets, who would otherwise be reluctant to venture into political activism.

Seen in this way, Confucian meritocratic civil society would be effective in initiating civic activism. But it seems to be quite limited in functioning as a civil society once the regime has been democratized, upon which what is at stake, we are told by liberals, is no longer mobilizing the people and creating a counterpublic, but rather accommodating the plurality of interests, values, and faiths in an orderly fashion under the constitutional structure governed by the democratic principle of equality. But is there an ineluctable reason that a civil society that can accommodate the plurality of interests, values, and faiths in an orderly and egalitarian fashion must be a liberal pluralist civil society? Notice that by nature, liberal pluralist civil society is socially conservative in the sense that its primary concern is to create a space where personal and associational interests, rights, and freedoms can be best protected or exercised within the constitutional boundary (Cahoone 2002), not so much to create a counterpublic space which aims to challenge the very (quasi-)constitutional limit authorized by a non-democracy. It also generates an intermediary social sphere where private individuals, otherwise atomistic, can be inculcated in the virtue of civility, reconnected with others, and reborn as social beings who are in a symbiotic relationship with the community (Glendon and Blankehorn 1995). In the course of liberal pluralization of civil society, however, the initial political energy of civil society often gets lost, along with its enthusiasm to assert the people's collective self-government as well as its power to redesign the direction of the polity according to the general will. Given that liberal pluralism supports a form of civil society that is purportedly congruent with liberal constitutionalism designed to constrain the assertion of popular sovereignty as best shown in its valorization of judicial review as the most effective instrument of counter-majoritarianism (Macedo 2001), it is hardly surprising that liberal pluralist civil society is critically at odds with the politics of square of the kind Confucian meritocratic civil society promotes. It may provide social capital that can fight against atomistic individualism and social anomie but it is doubtful that it can offer itself as a powerful political bulwark for public freedom and civic activism.

In my view, the civil society of the Candlelight Revolution represented a novel mode of civil society that strikes a complex middle ground between the minjung movement and the new citizen's movement, between civic-political activism and social pluralism, and between Confucian meritocratic civil society 
and liberal civil society. While being the culmination of the citizens' movement that had emerged in the post-democratic context as a new mode of organizing and expressing the power of democratic citizens, the candlelight protest went far beyond merely forging social capital that helps bridge various social differences and bring them under one civil society to which everyone belongs equally as citizens, when it evolved within the existing democratic constitutional structure into a political revolution in which the citizens themselves were empowered as super-citizens. In participating in the public protest, citizens were transformed into active political agents who reclaim their sovereign status, hijacked by the president's "betrayal of public trust," 26 and demand fundamental reform of the Korean polity that in their judgment should begin with removal of a bad ruler.

We can call this alternative mode of civil society a Confucian democratic civil society, at the core of which is a strong ethico-political nature supplemented by its great respect for constitutional politics. On the one hand, like Confucian meritocratic civil society, Confucian democratic civil society is deeply inspired by the Korean Neo-Confucian tradition of social criticism, the moral and political autonomy of those who are committed to the people's well-being, and political activism motivated by such moral commitment. On the other hand, however, Confucian democratic civil society is neither led by select super-citizens nor does it aim to create a counterpublic space outside a normal constitutional politics. Though retaining civic enthusiasm to keep the government on the right track, informed in part (but importantly) by the traditional Confucian conception of the good government, Confucian democratic civil society parts company with its meritocratic counterpart by pursuing this ethical ideal within the existing democratic constitutional structure, even when it strives for reform. It is a civil society that is particularly suited for a traditionally Confucian society that has undergone democratic transformation-or simply, suited for a Confucian democracy, a democracy whose underlying principles, public institutions, and social practices, which are all of the Western provenance, are in constant negotiation with the existing Confucian societal culture that still informs the habits of the heart of the local people. ${ }^{27}$

The idea of Confucian democratic civil society provides a useful theoretical framework to make sense of the cultural dimension of the Candlelight Revolution, which is difficult to capture from the perspective of liberal pluralist civil society. Our next question, then, is precisely how Confucian the Candlelight Revolution was in terms of its motivation and moral discourse.

\section{Lighting Candles for Our Country's Right Name}

Like other similar mega public protests that took place in Korea, the Candlelight Revolution initially began as a series of public remonstrations by ordinary citizens, joined by university professors and public intellectuals issuing a Declaration of the Current Situation (siguksŏnŏn 시국선 언), against the president who, according to the KCC, is supposed to be "the symbolic existence personifying the rule of law and the observance of law toward the entire public." 28 However, KCC's understanding of the president only partially captures what is commonly expected of the president in Korea. For the Korean people, the president is not merely the head of the state who has a legal and democratic procedural mandate to carry out his or her public duties-most important of which is to protect citizens' constitutional rights-in accordance with the constitution and other statutory laws, only grave violations of which can remove him or her from office. This formal definition of the president focuses purely on the office's legal and democratic authority within the liberal democratic constitutional structure but falls far short of addressing the normative ideal of moral leadership expected of the nation's highest political leader.

26 This is the expression that the Korean Constitutional Court employed when it described the gravity of Park's wrongdoing as being sufficient to warrant her impeachment (KCCR, 2016Hŏn-na1).

27 I discuss how this type of democracy can be formed and valued in East Asia in Kim $(2014,2016)$.

28 The KCC provided this understanding of the president in the Korean constitutional structure when it adjudicated President Roh Mu-hyun's impeachment in 2004 (KCCR, 2004Hŏn-Na1). 
No doubt, it was the Choi scandal and the president's legal violations involved in it that prompted Koreans to organize public protests. But was the president's violation of the law the only reason for the revitalization of mass civic activism? What made the Korean people so convinced that the president's illegal misconduct was "grave" enough to warrant her impeachment? In answering these questions, it is highly suggestive that it was the president herself who helped transform what had begun as public remonstrations into an all-encompassing political movement, calling not only for impeaching the president but also for a total change of the Korean polity, when she made a public statement (a third one to be precise) on 29 November 2016. In this statement intended to be a public apology, Park refused to step down, denying her complicity in the Choi scandal, while only apologizing for her failure to manage well the people around her, and defending her illegal support for the foundations run by Choi as resulting from her selfless concern with the public good. The public uproar that followed was not simply due to the fact that the president had violated the law, which should be the sole concern of the constitutional court in deliberating her impeachment in light of liberal constitutionalism, but, more importantly, her utter failure to live up to the normative ideal of the nation's highest political leader widely held among the Korean people. What then does this normative ideal consist of?

In the face of staggering civic pressure to impeach the president, the National Assembly of Korea finally passed the impeachment motion on 9 December 2016 on the ground of the president's "extensive and serious violations of the Constitution and the law." More specifically, the motion contained eight main accusations under two rubrics-first, violation of the constitution and second, violation of the statutory laws. Under the first rubric, the president was accused of violations of (a) popular sovereignty and other duties to uphold the Constitution; (b) the constitutional principle of equality and the president's right to appoint or dismiss public officials; (c) the presidential duty to uphold free market order and the right to private property; (d) the right to freedom of speech; and (e) protection of the right to life. Under the second rubric, the charges consisted of (f) abuse of power, (g) extortion, and (h) leakage of confidential documents. What is interesting is that except for (a) and (e), none of these formal charges, which directly concern citizens' basic rights, liberties, opportunities or what John Rawls calls "constitutional essentials", was at the center of the public discourse that invigorated civil society, even though citizens were strongly convinced that the president had committed all of these wrongs, and thus was legally culpable. Since (a) concerns an abstract principle governing the basic duties of the president in any constitutional democracy and it is expected to be invoked in the constitutional adjudication of a presidential impeachment, what is truly remarkable about the Candlelight Revolution is why (e) was so important for the Korean public and, as will be discussed shortly, how it had anything to do with the normative ideal of the nation's highest political leader.

Though the National Assembly included the violation of the duty to protect citizens' right to life as one of the reasons for impeaching the president, it is hard to deny that inclusion of this charge in the impeachment motion was largely due to enormous popular pressure and had nothing to do with the Choi scandal. Unlike other charges, violation of the duty to protect citizens' right to life was brought up based on a widely held popular observation that the president had failed to respond effectively to "the Sewol incident" that had occurred two years earlier, which caused the deaths of more than three hundred people, mostly secondary school students on a field trip, who were on a ferry named "Sewol". When this tragedy occurred, the president did not appear publicly for as long as seven hours, did not give any proper orders for rescuing the people on a sinking ship, and when she finally showed up, she appeared clueless about what had been going on, making the majority of Koreans watching the whole incident on live broadcast dumbfounded, then enraged (also see Kim 2017, pp. 7-10).

For the members of the National Assembly who were under staggering pressure to channel the citizens' civic anger and rage into the process of impeachment, "violation of the constitutional duty to protect citizens' right to life" was the best language available to them because apparently it was the only legitimate language that Korea's liberal-democratic constitutional system could make sense of and would legally recognize. From the standpoint of ordinary Koreans, however, what was at issue was not necessarily the right to life, typically referenced in cases of death penalty, terminal illness, 
or abortion, but rather the most basic well-being of citizens, namely, their physical survival. Many Koreans found the president completely irresponsible when she disappeared for unknown reasons at the moment she was desperately needed and they also found her insincere when she offered neither an explanation for her disappearance nor an apology for her failure to fulfill her duty as both legally stipulated and public-culturally expected. As the citizens watched the president take no responsibility for the deaths of the people who could have survived if she had taken proper action during the short window, as well as show no genuine sense of empathy toward the victims' families when she refused to meet them despite their repeated requests, the people realized that the president was critically lacking something important, something that they would normally expect from the nation's highest political leader, but that which the Korean constitution does not specify or formally require. This "something" that the president was critically devoid of was the virtue of sincerity and an empathetic heart. However, at the time of the Sewol incident, the Korean public did not know how to process their frustration with the president in a constitutionally acceptable manner but merely remonstrated with her in the open space of civil society, because there was no constitutional resource available on the basis of which to formally express the public's blame for her insincerity, irresponsibility, and lack of an empathetic heart, or all put together, her fatal failure to exercise a benevolent government.

For the Korean public, the Choi sandal only confirmed their deep suspicion that the president lacks the core virtues that they believe are essential for good political leadership. Now, on top of her putative legal crimes, when she once again shirked her responsibility for the Choi scandal and instead rationalized her misconduct and legal violations as unintended outcomes of a selfless commitment to the public good, Korean citizens, though initially willing to give her an opportunity to keep face by letting her step down, finally gave up all hope on her as a political leader and decided to put her out of office via impeachment by pressuring the legislature.

Two points are important to note here. First, as the KCC rightly noted later, though with some ambiguity, it was not so much the president's legal violations as such but her "betrayal of the trust of the people" that drove the people to the streets, initially as a sign of remonstration, then as that of protest and contention. The KCC noted that the purpose of impeachment was to deprive the president of the (institutionally conferred) trust of the people (via democratic election). From the perspective of democratic legitimacy, the KCC concluded, "there are grounds for impeachment when the President is found to have betrayed the trust of the people by committing crimes that are serious enough to warrant removal of him or her from office during his or her tenure" (KCCR, 2016Hŏn-na1, p. 18). However, if the president's legal violation itself implies her forfeiture of the trust of the people, why should there be an additional "test of gravity", according to which impeachment of the president is justified only if the crime is grave enough to ensure that the expected public interest incurring from removal of her from office clearly overrides the public cost that would follow? That is, if the president's legal violation alone satisfies the betrayal of public trust condition, how can the gravity condition be met?

While the democratic procedural interpretation of "the betrayal of the trust of the people" was supposed to generate this legal conundrum and it was indeed the very problem with which the KCC later struggled, ${ }^{29}$ for Korean citizens the problem was not as complicated as this legal judgment. For those who were participating in the public protest, the president betrayed not only democratic trust with her crimes, but additionally, the traditional Confucian notion of trust between the ruler and the ruled, according to which the ruler serves the well-being of the people while the people reciprocate the ruler's care with voluntary cooperation and compliance. ${ }^{30}$ From the standpoint of

29 I discuss this issue extensively in Kim (). As I argue in the cited paper, it is quite clear that Korean constitutional justices (at least several of them) were influenced, albeit implicitly, by the Confucian moral ideals of good government and good leadership, strongly resonating with Korean Confucian democratic civil society.

30 On this point, Chan (2014, p. 40) writes, "A personal quality essential to authority is trustworthiness. Confucians think that ultimately the effectiveness of political power rests on the level of trust the people have in their ruler. A government must have the people's cooperation and compliance in order to accomplish its tasks." 
civil society, the gravity condition was clearly met when the president was found to have violated this second requirement of public trust, although this moral and purely normative binding is only tacitly acknowledged in Korean politics and therefore has no (direct) legal foundation in the Korean Constitution-hence the court's trouble in adjudicating the gravity condition.

Second, the fact that the president's response to the victims of the Sewol incident and their families was one of the most important factors that galvanized the Korean civil society during the Candlelight Revolution shows that Koreans held a normative ideal of democratic political leadership, which cannot be fully satisfied by its liberal ideal that holds rational accountability as its central concern. When it was later disclosed to the public that the president was at her private residence during her regular working hours as more than three hundred people drowned and that she never showed an interest in meeting the victims' families, their repeated requests and public support for them notwithstanding, it was clear that the president was far from the traditional ideal of the virtuous ruler who cares for and is capable of empathizing with the people.

Though this empathetic dimension of political leadership is less emphasized in liberal constitutionalism, it is the central feature of Confucian leadership as strongly vindicated in the ideal of benevolent government. While the Confucian benevolent government does not rest on the naive belief that a virtuous ruler always produces a good government, its driving force certainly comes from the ruler's care and responsibility for the people, even when the problem at hand (the most serious of which is suffering of the people) is not directly caused by his own misrule. ${ }^{31}$ When Koreans were raising candles and demanding the president's resignation and eventually her impeachment, they might not have actually believed that she had proactively violated the citizens' right to life. As it turned out, the KCC did not uphold this charge when brought by the National Assembly. What is clear though is that in the eyes of the Koreans the president did not possess the right moral character expected of the nation's highest political leader. When it was repeatedly proven that she not only lacked core virtues for good leadership such as benevolence, sincerity, trustworthiness, responsibility, and compassion, but rather had gone actively against the ideal of good government by being callous to the suffering of the people and entrusting the government to a friend who was totally unqualified and had no interest in the public good, many ordinary Koreans finally came to the conclusion that she was unsuited for this post and should be removed immediately.

In the end, for the Korean people, the president failed to live up to the "right name" of her office, the Confucian litmus test for good government, as much as she failed in democratic legitimacy. It should be reminded that when asked what he would do first if entrusted with the government, Confucius replied that he would "rectify the names" (zheng ming 正名) before anything else because "if names are rectified, things will be successfully accomplished" (Analects 13.3). ${ }^{32}$ More specifically, in advancing the rectification of the names as the method of Confucian statecraft, Confucius articulates its content as nothing less than "letting the ruler be a ruler, the minister be a minister, the father be a father, and the son be a son" (Analects 12.11, my translation). Accordingly, bad government arises when members of society do not conduct themselves according to the normative ideal of the social positions that they hold. Though, ideally, good government can be attained when all members of society fulfill their social roles faithfully in accordance with what is morally intended by the titles of such roles, it begins with the ruler's ability to rectify (zheng 正) himself and put himself on the right track of the Way. Hence, Confucius's famous statement, “To govern (zheng 政) is to correct (zheng 正). If you [the ruler] set an example by being correct, who would dare to remain incorrect?" (Analects 12.7) According to Confucius, self-rectification is not merely to follow the conventional social roles blindly (Roetz 1993). It involves critical self-reflection and a rigorous process of self-discipline that enables one to overcome one's untutored private desires and follow the social patterns expressive of the Way (thus

31 On the Confucian non-causal conception of political responsibility, see Kim (2010).

32 Unless noted otherwise, throughout this paper the English translations of the Lunyu 論語are adapted from Confucius (1979). 
not any social norms), the faithful practice of which would lead him or her to acquire the virtue of benevolence (ren 仁) (Analects 12.1), the Confucian moral virtue par excellence, and thus enabling a benevolent government.

Seen in this way, the greatest wrong that the president committed was that she did not act like the nation's highest political leader and she actively violated norms associated with her moral and political role as culturally understood, which is more than just following the public duties attached to the office of the president as stipulated by the constitution, although she did fail in this as well. Otherwise stated, the president's legal violation, which was to be the only concern of the KCC in adjudicating her impeachment, was one important reason for collective civic activism, but the Candlelight Revolution was about much more. It was about the failure of a new democracy in living up to its right name. In its right name, Korean democracy ought to have operated on the Way in which (West-originated) democratic principles and traditional Confucian values are dialectically intertwined, it ought to have had a national leader equipped with character traits necessary for good government, and ultimately, it ought to have developed a political system that not only ensures protection of liberal rights but also helps realize citizens' collective self-government in light of their shared conception of the good life that is at once liberal and Confucian.

For Koreans, the Choi scandal and the president's failed leadership symbolized the fatal failure of the promise of this democracy ("Confucian democracy" as I called it earlier) and this realization inevitably brought them to seek something far more fundamental than the impeachment of the sitting president-a democracy of its right name. As such, what had originally began as public remonstration with the president underwent a radical self-transformation when the people participating in it finally turned their attention to the question of what it means to live in a democracy. Participants of the June Uprising of 1987, preoccupied with removing the evils of a repressive government and bringing about a procedural democracy that can protect basic rights, could not think deeply about this ontological meaning of democracy as a way of life. The participants of the 2016-2017 candlelight protest, however, gave democratic life a new political significance by affiliating the impeachment of the president who violated both law and traditional norms of good government with a more fundamental question about the nature of their democratic life and constitutional system. For them it had to be an event that would signal a radical departure from "accumulated evils" of the existing mode of democracy (or pseudo-democracy) and make the Korean polity start anew in light of its democratic promise. Therefore, it must go beyond mere political protest and evolve into a "revolution" in which bad old practices are replaced by reformed institutions and practices. Finally, the candlelight protest grew to become a political revolution when ordinary people brought down the ruler with their own power and in their own name for the first time in Korean history, yet in accordance with constitutional procedure and the democratic duty of civility.

\section{Conclusions}

That the Candlelight Revolution was strongly motivated by moral concerns closely affiliated with Korea's traditional Confucian political ideal and culture does not necessarily mean that Confucianism was its only motivating force. Nor does it imply that all Confucian motivations that have been identified in this paper were directly relevant to the problem at hand. For instance, and as noted already, given the only tangential relation between the Sewol incident and the Cho scandal, it is arguable whether Korean civil society was rightly motivated in launching a mass public protest against the president when their political action was in part propelled by their frustration with the way in which she had responded to the Sewol incident. Again, this was a critical point for the justices in the KCC in adjudicating the impeachment, and, to be sure, their first task was to disentangle the legal questions surrounding this profoundly political case from all other moral claims and political contentions arising from civil society, although it is another matter whether KCC indeed handled the case consistently from its professed apolitical stance. The point that I am trying to make in this paper is that the Korean civil society of the Candlelight Revolution can be called a Confucian democratic 
civil society not least because of its remarkable distance from liberal pluralistic civil society but also because of the saliently Confucian content of the moral discourse that motivated it.

In Korean political studies, Confucian civil society is one of the most underdeveloped and underappreciated concepts. Furthermore, a meritocratic version of Confucian civil society, which is more popular among the Chinese advocates of civil society, does reveal its critical limitations in the democratic context that defines Korean politics after democratization, where public equality has become an inviolable social norm. Confucian democratic civil society provides a useful theoretical concept that can help us to not only philosophically reconstruct a normatively attractive and socially practicable vision of civil society in a society that is politically democratic and culturally Confucian, but also to understand as well as evaluate the social practice of civic activism that is taking place in East Asian societies of the Confucian heritage from a more culturally nuanced perspective. It is hoped that our cultural analysis of Korea's Candlelight Revolution demonstrates the conceptual utility of Confucian democratic civil society in the evaluative-empirical study of civil society in East Asia.

Funding: This work was supported by the Ministry of Education of the Republic of Korea and the National Research Foundation of Korea (NRF-2017S1A3A2065772).

Conflicts of Interest: The author declares no conflicts of interest.

\section{References}

Ackerly, Brooke A. 2005. Is Liberalism the Only Way toward Democracy? Confucianism and Democracy. Political Theory 33: 547-76. [CrossRef]

Angle, Stephen C. 2012. Contemporary Confucian Political Philosophy: Toward Progressive Confucianism. Cambridge: Polity.

Angle, Stephen C., and Justin Tiwald. 2017. Neo-Confucianism: A Philosophical Introduction. Cambridge: Polity.

Bae, Mun-jo, and Se-jeong Park. 2013. Taehakseng-ŭi hyo-e taehan insikkwa kachokgach'igwan-e yŏnghyang-ŭl ich'inŭn pyŏnin [Consciousness of Filial Piety and Family Values in College Students]. Journal of the Korean Contents Association 13: 275-85. [CrossRef]

Cahoone, Lawrence E. 2002. Civil Society: The Conservative Meaning of Liberal Politics. Malden: Blackwell.

Chan, Joseph. 2014. Confucian Perfectionism: A Political Philosophy for Modern Times. Princeton: Princeton University Press.

Cho, Hein. 1997. The Historical Origin of Civil Society in Korea. Korea Journal 37: 24-41.

Cho, Tae-yŏp, and Ch'ŏl-kyu Kim. 2007. Han'guk Siminsahoe-ŭi Kujo-wa Tonghak [The Structure and Dynamic of Korean Civil Society]. Seoul: Jimmundang.

Choi, Jang-Jip. 2009. Minjung-eš̆ Simin-ŭro [From People to Citizens]. Seoul: Tolbegae.

Cohen, Jean L., and Andrew Arato. 1994. Civil Society and Political Theory. Cambridge: The MIT Press.

Confucius. 1979. The Analects. Translated by D. C. Lau. New York: Penguin.

De Bary, William Theodore. 1983. The Liberal Tradition in China. New York: Columbia University Press.

Deuchler, Martina. 1992. The Confucian Transformation of Korea: A Study of Society and Ideology. Cambridge: Council on East Asian Studies, Harvard University.

Diamond, Larry. 1999. Developing Democracy: Toward Consolidation. Baltimore: Johns Hopkins University Press.

Doucette, Jamie. 2017. The Occult of Personality: Korea's Candlelight Protests and the Impeachment of Park Geun-hye. Journal of Asian Studies 76: 851-60. [CrossRef]

Galston, William A. 2002. Liberal Pluralism: The Implications of Value Pluralism for Political Theory and Practice. Cambridge: Cambridge University Press.

Glendon, Mary A., and David Blankehorn, eds. 1995. Seedbeds of Virtue: Sources of Competence, Character, and Citizenship in American Society. Lanham: Madison Book.

Howard, Marc M. 2003. The Weakness of Civil Society in Post-Communist Europe. Cambridge: Cambridge University Press.

Keane, John. 1998. Civil Society: Old Images, New Visions. Stanford: Stanford University Press.

Kim, Dong-Choon. 2006. Growth and Crisis of the Korean Citizens' Movement. Korea Journal 46: 99-128.

Kim, Nan. 2017. Candlelight and the Yellow Ribbon: Catalyzing Re-Democratization in South Korea. Asia-Pacific Journal: Japan Focus 15: 1-17. 
Kim, Sŏng-chae. 2018. Orak k'ŏmyunikeishyŏn: Ch'oppulhyŏkmyŏng, punno-esŏ yuhŭi-ro [The Communication of Entertainment: The “Candlelight Revolution", from Anger to Amusement]. Hyŏndae yurŏpch'ŏrak yŏn'gu 50: 167-205.

Kim, Sungmoon. 2008. Transcendental Collectivism and Participatory Politics in Democratized Korea. Critical Review of International Social and Political Philosophy 11: 57-77. [CrossRef]

Kim, Sungmoon. 2010. The Secret of Confucian Wuwei Statecraft: Mencius's Political Theory of Responsibility. Asian Philosophy 20: 27-42. [CrossRef]

Kim, Sungmoon. 2011. Confucian Constitutionalism: Mencius and Xunzi on Virtue, Ritual, and Royal Transmission. Review of Politics 73: 371-99. [CrossRef]

Kim, Sungmoon. 2014. Confucian Democracy in East Asia: Theory and Practice. New York: Cambridge University Press.

Kim, Sungmoon. 2016. Public Reason Confucianism: Democratic Perfectionism and Constitutionalism in East Asia. New York: Cambridge University Press.

Kim, Sungmoon. Forthcoming. From Remonstrance to Impeachment: A Curious Case of "Confucian Constitutionalism" in South Korea. Law and Social Inquiry.

Kim, Sunhyuk. 2000. The Politics of Democratization in Korea: The Role of Civil Society. Pittsburg: University of Pittsburg Press.

Kim, Sunhyuk. 2004. South Korea: Confrontational Legacy and Democratic Contributions. In Civil Society and Political Change in Asia: Expanding and Contracting Democratic Space. Edited by Muthiah Alagappa. Stanford: Stanford University Press, pp. 138-63.

Kim, Yong-ki, and Dong-hee Lee. 2017. Daet'ongnyŏng t'anhaek ch'otppulchipoe-ŭi kyoyukchŏk ŭimi [The Educational Implications of Candlelight Vigil Protests for President Impeachment]. Hang'uk K'ontenchŭhakhoe Nonmunchip 17: 311-18.

Koo, Hagen. 1993a. Strong State and Contentious Society. In State and Society in Contemporary Korea. Edited by Hagen Koo. Ithaca: Cornell University Press, pp. 231-49.

Koo, Hagen. 1993b. The State, Minjung, and the Working Class in South Korea. In State and Society in Contemporary Korea. Edited by Hagen Koo. Ithaca: Cornell University Press, pp. 131-62.

Kymlicka, Will. 1995. Multicultural Citizenship. Oxford: Oxford University Press.

Lee, Junghoon. 2015. Confucianism and the Meaning of Liberalism in the Contemporary Korean Legal System. In Confucianism, Law, and Democracy in Contemporary Korea. Edited by Sungmoon Kim. London: Rowman and Littlefield International, pp. 149-71.

Lee, Namehee. 2007. The Making of Minjung: Democracy and the Politics of Representation in South Korea. Ithaca: Cornell University Press.

Lee, Seung-Hwan. 2003. The Concept of Gong in Traditional Korea and Its Modern Transformations. Korea Journal 43: 137-63.

Lee, Su-Hoon. 1993. Transitional Politics of Korea, 1987-1992: Activation of Civil Society. Pacific Affairs 66/3: 351-67. [CrossRef]

Linz, Juan J., and Alfred Stepan. 1996. The Problem of Democratic Transition and Consolidation. Baltimore: Johns Hopkins University Press.

Macedo, Stephen. 2001. The Constitution, Civic Virtue, and Civil Society: Social Capital as Substantive Morality. Fordham Law Review 69: 1573-93.

Madsen, Richard. 2002. Confucian Conceptions of Civil Society. In Alternative Conceptions of Civil Society. Edited by Simone Chambers and Will Kymlicka. Princeton: Princeton University Press, pp. 190-204.

Metzger, Thomas A. 2001. The Western Conception of Civil Society in the Context of Chinese History. In Civil Society: History and Possibilities. Edited by Sudipta Kaviraj and Sunil Khilnani. Cambridge: Cambridge University Press, pp. 204-31.

Park, Chong-Min, and Doh Chull Shin. 2006. Do Asian Values Deter Popular Support for Democracy in South Korea? Asian Survey 46: 341-61. [CrossRef]

Park, Mi. 2005. Organizing Dissent against Authoritarianism: The South Korean Student Movement in the 1980s. Korea Journal 45: 261-89.

Rawls, John. 1993. Political Liberalism. New York: Columbia University Press.

Roetz, Heiner. 1993. Confucian Ethics of the Axial Age. Albany: State University of New York Press. 
Rosenblum, Nancy L. 1998. Membership and Morals: The Personal Uses of Pluralism in America. Princeton: Princeton University Press.

Shils, Edward. 1997. The Virtue of Civility. Edited by Steven Grosby. Indianapolis: Liberty Fund.

Shin, Jong-Hwa. 2000. The Limits of Civil Society: Observations on the Korean Debate. European Journal of Social Theory 3: 249-70.

Shin, Kwang-Yeong. 2006. The Citizens' Movement in Korea. Korea Journal 46: 5-34.

Son, Ho-ch'ŏl. 2017. Ch'oppulhyŏkmyŏng-kwa 2017nyŏn ch'eje [The Candlelight Revolution and the 2017 System]. Seoul: Sogang University Press.

Swidler, Ann. 2000. Cultural Power and Social Movements. In Culture and Politics: A Reader. Edited by Lane Crothers and Charles Lockhart. New York: St. Martine's Press, pp. 269-83.

Tan, Sor-hoon. 2003. Can There Be a Confucian Civil Society? In The Moral Circle and the Self: Chinese and Western Approaches. Edited by Kim-Chong Chong, Sor-hoon Tan and C. L. Ten. Chicago: Open Court, pp. 193-218.

Tu, Wei-ming. 2006. Munmyŏngdŭl-ŭi Taehwa [A Dialogue among Civilizations]. Translated by T'ae-sŏng Kim. Seoul: Hyumŏnisŭtŭ.

Wedeen, Lisa. 2002. Conceptualizing Culture: Possibilities for Political Science. American Political Science Review 96: 713-28. [CrossRef]

Wood, Alan T. 1995. Limits to Autocracy: From Sung Neo-Confucianism to a Doctrine of Political Rights. Honolunu: University of Hawaii Press.

Wu, In-su. 1999. Chosŏnhugi Sallimseryŏk Yŏn'gu [A Study on the Backwoods Literati as Political Forces in the late Chosŏn Period]. Seoul: Ilchogak.

(C) 2018 by the author. Licensee MDPI, Basel, Switzerland. This article is an open access article distributed under the terms and conditions of the Creative Commons Attribution (CC BY) license (http:/ / creativecommons.org/licenses/by/4.0/). 